REVISION

\title{
PINK DISEASE, A REVIEW OF AN ASYMPTOMATIC BACTERIAL DISEASE IN PINEAPPLE
}

\author{
VIANEY MARÍN-CEVADA² \& LUIS ERNESTO FUENTES-RAMÍREZ³
}

\begin{abstract}
Pink disease is an asymptomatic pineapple disease in the field and is evidenced with a reddark coloration when the infected fruit is processed to obtain products such as juice, jam, and preservatives. Tatumella morbirosei and T. ptyseos (formerly Pantoea citrea) have been demonstrated as causal agents. Although T. morbirosei and T. ptyseos have been well studied, there are currently no cost effective control methods in pineapple cultivation. The purpose of this review is to summarize the significant and updated research on the role of pink disease in pineapple.
\end{abstract}

Index terms: pineapple, phytopathogen, $g d h B$, biocontrol.

\section{DOENÇA ROSADA, UMA REVISÃO DE UMA DOENÇA ASSIMTOMÁTICA BACTERIANA DO ABACAXI}

\begin{abstract}
RESUMO - Doença rosada ou Pink disease é uma doença assintomática do abacaxi no campo, eque é evidencia com uma coloração vermelho - escura, quando a fruta infectada é processada para a obtenção de produtos como suco, geléia, e conservantes. Tatumella morbirosei e T. ptyseos (antigo Pantoea citrea) tsão os agentes causáis dessa doença. Embora T. morbirosei e T. ptyseos foramtenham sido bem estudadas, até o presente não existem métodos eficientes de controle da Pink disease de abacaxi. O objetivo da presente revisão é sumarizar as pesquisas significativas e atualizadas pesquisasobre o papel de Pink disease no cultivo do abacaxizeiro.
\end{abstract}

Termos para indexação: abacaxi, fitopatógeno, $g d h B$, biocontrole.

\section{INTRODUCTION}

Pink disease is an important global threat to pineapple production, especially for the fruit industry. The reported causal agents are Tatumella morbirosei (formerly Pantoea citrea) and Tatumella ptyseos, both belonging to the Enterobacteriaceae (CHA et al.,1997a; MARIN-CEVADA et al., 2010). Pink disease has been reported from Australia, Hawaii, Mexico, the Philippines, South Africa, and Taiwan (MARÍN-CEVADA et al., 2006; ROHRBACH, 1983). Cost-effective management strategies for effective control of the disease are still not available. The current schemes consist mainly of insect control, since it has been supposed that insects play a role in the transmission of the pathogen (KADO, 2003). Additionally, plant breeding for obtaining resistant cultivars might be an alternative to overcome the problem (Kado, 2003).

\section{Economic Status of Pineapple}

The tropical fruits most cultivated in the world are bananas, mangos, avocados, papayas and pineapples (FAO 2003) with an estimated total worldwide production of about 160 million tons in 2012 (http://faostat3.fao.org/download/Q/QC/E).

About $98 \%$ of tropical-fruit production is taking place in developing countries and $80 \%$ of the world import trade for these fruits is directed to developed countries (http://fao.org/docrep/006/ y5143e/y5143e1a.htm). Pineapple had a worldwide gross production valued at $\$ 17$ billion in 2012 (http:// faostat3.fao.org/download/Q/QV/E).

A large amount of the pineapple trade consists of processed products, such as canned slices and juice (BARTHOLOMEW et al., 2003). Thailand, Brazil, the Philippines, Indonesia, and Costa Rica are the major producers of fresh fruit pineapples, and Costa Rica ranked as the major world pineapple exporter

\footnotetext{
1(Trabalho 151-15). Recebido em: 02-06-2015. Aceito em 01-09-2016.

${ }^{2}$ Vianey Marín-Cevada, Centro de Investigaciones en Ciencias Microbiológicas, ICUAP, Benemérita Universidad Autónoma de Puebla, Mexico. Email: vimalex7@gmail.com

${ }^{3}$ Luis Ernesto Fuentes-Ramírez, Centro de Investigaciones en Ciencias Microbiológicas, ICUAP, Benemérita Universidad Autónoma de Puebla, Mexico. Email: luis.fuentes@correo.buap.mx, corresponding author
} 
in 2011 with 1.75 million metric tons (MMT) (http:// faostat3.fao.org/faostat-gateway/go/to/browse/T/ $\mathrm{TP} / \mathrm{E})$. The world production of canned pineapples has shown a tremendous increase over the last decade or so (http://faostat3.fao.org/faostat-gateway/go/to/ browse/Q/QC/E) (Table 1). Similarly, the production of pineapple juice has showed a notable increase in the last years (http://faostat3.fao.org/faostat-gateway/ go/to/browse/Q/QC/E) (Table 1).

The pineapple plant [Ananas comosus (L.) Merr. var. comosus] is widely distributed in the New World and shows a great adaptability to ariedseveral habitats. Pineapple is one of the most ancient American crops and was domesticated and dispersed several thousand years ago by Amerindian peoples in the Orinoco and Amazon basins (COLLINS, 1960). This plant is a member of the Bromeliaceae family, which contains about 58 genera and 3352 species (LUTHER, 2012). "Smooth Cayenne" "Red Spanish", "Queen", "Abacaxi", and "MD2" are the principal pineapple grown cultivars (Bartholomew et al., 2003; LOEILLET et al.; 2011 UNCTAD http:// www.unctad.info/en/Infocomm/AACP-Products/ COMMODITY-PROFILE-Pineapple/).

The productivity of the pineapple depends on the control of factors such as water and nutrient supply (nitrogen, potassium, phosphorus, calcium, iron, magnesium, zinc, boron and other micronutrients), as well as management and control of pests and diseases (ZHANG et al., 1997).

\section{Pink disease of pineapple}

The pineapple plant is threatened by several phytopathogenic bacteria that are responsible for diseases like fruit collapse, marbling disease, fruit brown rot, anomalous proliferations and pink disease (Table 2),(JOHNSTON 1957;LIM;LOWINGS 1979; KORRES et al. 2010;SERRANO 1928;DAVIS ETAL. 2005;DAVIS et al. 2006; LYON 1915).

Among them, pink disease is of great importance because of its potential impact on the postharvest processes (CHA et al., 1997b). Pasteurized fruits affected by this disease produce brownish pigments, so the commodity becomes unmarketable (ROHRBACH, 1989; ROHRBACH; PFEIFFER, 1975) (Fig. 1). The challenge in the control of this disease is that infected plants remain asymptomatic in the field, making difficult to discriminate healthy from affected fruits (Pujol and Kado 1999). Unfortunately, cans of healthy fruit from the same lot of infected fruits are also commonly discarded by quality control, increasing the economic losses (CHA et al., 1997b).

\section{Causative agents of Pink Disease}

It has been suggested that this disease is caused by microorganisms of the families Acetobacteraceae and Enterobacteriaceae (BUDDENHAGEN; DULL, 1967; GOSSELE;SWINGS, 1986; KONTAXIS; HAYWARD, 1978; ROHRBACH; PFEIFFER, 1976). Almost four decades ago, an isolate obtained from a diseased fruit, did not show perceptible symptoms when it was inoculated in fresh fruits but induced discoloration after heating the inoculated fruits (Rohrbach and Pfeiffer 1976). The authors identified that strain as belonging to the species Enterobacter agglomerans (Pantoea agglomerans, GAVINI, et al., 1989) (CHO, et al., 1980; ROHRBACH; PFEIFFER, 1976). Afterwards, Pantoea citrea was identified as another causative microorganism (CHA, et al., 1997a), also in the Family Enterobacteriaceae. A wide taxonomic analysis of $P$. citrea strains causing pink disease showed their proper classification as the a-new species, Tatumella morbirosei, in a different Gyenus of Enterobacteriaceae and not as a species of Pantoea (BRADY et al. 2008; 2010). Furthermore, isolates obtained from pink disease affecting Mexican pineapple fruits were identified as belonging to the species $T$. ptyseos (MARÍN-CEVADA et al. 2010). Hence, at least those two species of the genus Tatumella are capable to cause pineapple pink disease.

\section{Epidemiology and other characteristics of pink disease}

Seasonality is probably an important factor in the appearance of the disease, since warm and humid environments promote the appearing of the phytopathogen. In our previous research we detected the presence of $T$. ptyseos in $48 \%$ of pineapples in the rainy season (MARIN-CEVADA, et al., 2010), and only $3 \%$ in the dry season (unpublished results of our group). Besides, the average bacterial number decreased from $10^{6} \mathrm{CFU} / \mathrm{g}$ of fruit to $10^{2} \mathrm{CFU} / \mathrm{g}$ of fruit in the rainy and dry season, respectively (MARIN-CEVADA, et al., 2010). In other geographic regions, the incidence of pink disease increases also in the rainy season, February, March and April in Hawaii and Taiwan, and August and September in the Philippines (HINE, 1976; ROHRBACH; JOHNSON, 2003; ROHRBACH; PFEIFFER, 1975). Other biological or environmental factors might be required for the bacterial outbreak, since not all the wet seasons shown higher incidence of pink disease (HINE, 1976). There is no consensus with regard to the entry of the pathogen into the plant. It has been suggested that bacterial cells come into contact 
with the nectar in the placental regions of flowers (ROHRBACK; PFEIFFER 1975). It has also been proposed that the bacteria involved in pink disease are transmitted to pineapple flowers by insects. The latter scenario is supported by the fact that spraying of crops with insecticide decreases the appearance of the disease (KADO, 2003). In addition, rain splash could disperse the pathogens from infected to healthy plants (HINE, 1976).

The biochemical basis of the pink discolouration in T. morbirose $i$ was elucidated by CHA et al., (1997b); PUJOL;KADO (1999; 2000). It is noteworthy that a biochemical basis of pink disease had been suggested by Buddenhagen and Dull since 1967. The pigmentation of affected fruit is initiated by the oxidation of glucose to gluconate by glucose dehydrogenase GdhB. $g d h B$ is induced by glucose in the stationary phase (PUJOL;KADO 1999). GdhB oxidizes gluconate to 2-keto-D-gluconate, which is subsequently converted to 2,5-diketogluconate by another dehydrogenase (PUJOL; KADO, 1999; 2000). It has been suggested that 2,5 -diketogluconate can form complexes with plant compounds produced at canning temperatures, or may dimerize, producing the decolorization (CHA et al., 1997b; KADO, 2003). Alternatively, 2-keto-D-gluconate present in infected fruits might suffer an accelerated heat oxidation to 2,5-diketogluconate. $g d h A$, a gene for a second glucose dehydrogenase in T. morbirosei, is expressed constitutively at low levels and does not participate in the generation of pink disease pigmentation (Pujol and Kado 1999). GdhB possesses a putative binding site for pyrroloquinolinequinone (PQQ). PQQ could be synthesized endogenously in T. morbirose $i$ since cell extracts show Gdh activity without adding an exogenous cofactor (Pujol and Kado 1999), and as a matter of fact, the T. ptyseos genome possesses at least one locus putatively implicated in PQQ biosynthesis (Acc. Num. WP_025901980).

\section{Control}

The application of insecticides in pineapple fields has been suggested to decrease the incidence of pink disease (KADO, 2003). Nevertheless, this practice could damage natural and human ecosystems and it is still unclear how insects and pink disease agents are related. Hence, it would be desirable to find alternative control methods including the production of resistant varieties and the use of biological control. In order to design suitable control and preventive measures, it is essential to get profound knowledge of all the elements of this disease. In combination with an insecticide, the saprophytic bacterium Bacillus gordonae have shown promising results for control of pink disease under laboratory and field conditions (KADO, 2003), but its effectiveness and economic benefits are yet to be evaluated.

Recently, our group searched for antagonists against $T$. ptyseos. Among dozens of isolates from pineapple plants, two of them that showed the greatest inhibitory activity in culture media against T. ptyseos, where selected for determining their activity in assays in association with plants (MARÍNCEVADA et al., 2012). The antagonism assays were carried out in double-layer plates, in liquid cultures, and in micropropagated inoculated pineapple plantlets (cv. Smooth Cayenne). The numbers of T. ptyseos growing for $96 \mathrm{~h}$ in liquid co-culture with the isolate UAPS07070 were three orders of magnitude less thant when growing alone (MarinCEVADA et al., 2012). The antagonistic bacterium was also able to abate the brownish pigmentation of culture medium produced by the pathogen in cocultures (MARÍN-CEVADA et al., 2012). It is still unknown if that observation was caused by the drop of $T$. ptyseos population itself, or by an inhibition of the oxidation pathway. In 60 days old inoculated pineapple plantlets, the numbers of $T$. ptyseos were lower in co-inoculation with the isolate UAPS07070 than in lonely inoculation. Particularly, two orders of magnitude less inside the roots and three orders less in the rhizosphere (MARIN-CEVADA et al., 2012).

Bacterial exudates produced by isolate UAPS07070 inhibited the growth of T. ptyseos UAPS07007 in rich medium and also on rich solid medium saturated with $\mathrm{FeCl}_{3}$ (Fig. 2). Since siderophores synthesis is inhibited under high $\mathrm{Fe}^{3+}$ concentrations, it seems unlikely that such compounds could be responsible for the antagonism between this isolate and T. ptyseos. By comparison of partial nucleotide sequences of 16S rRNA and $r e c A$ genes, the antagonistic isolate was identified as Burkholderia gladioli, a bacterium included in the potential pathogens phylogenetic clade of this genus (SUÁREZ-MORENO et al., 2012). That cluster also includes the species of the Burkholderia cepacia complex, the "pseudomallei" group, and $B$. glumae among others. Hence, the likely pathogenic characteristics of B. gladioli UAPS07070 hampers its use as a biocontrol agent of pink disease. An alternative to the direct use of $B$. gladioli could consist of the isolated antagonistic substance, or the inoculation of non-pathogenic GMOs designed to synthesize it. Thus, it is crucial to determine the molecular mechanisms responsible for competition between pineapple bacteria. 


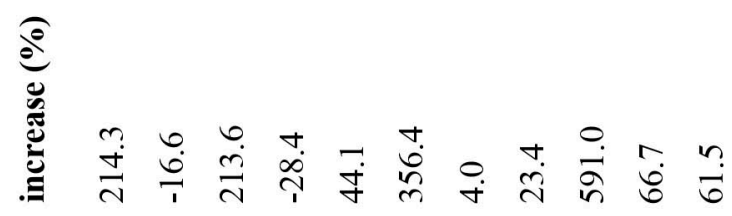

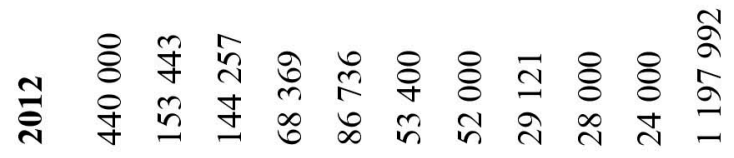

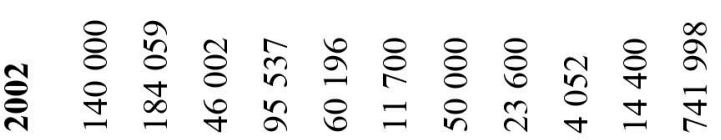

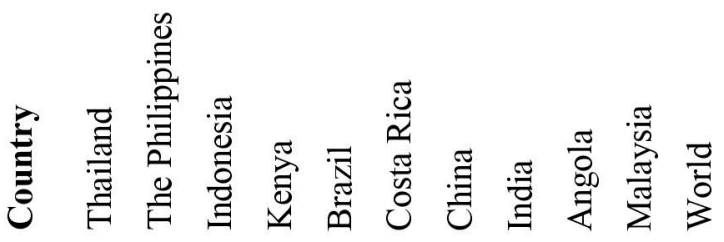

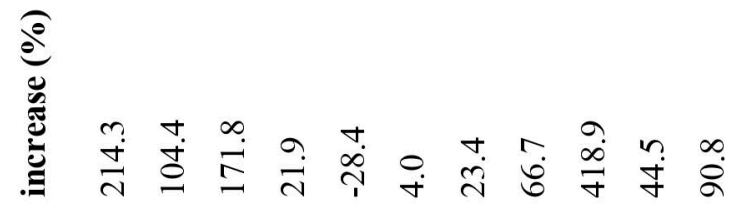

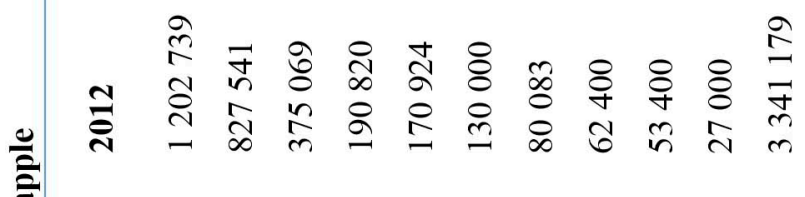

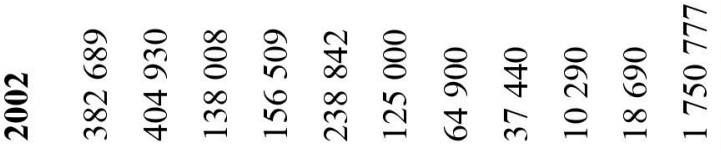

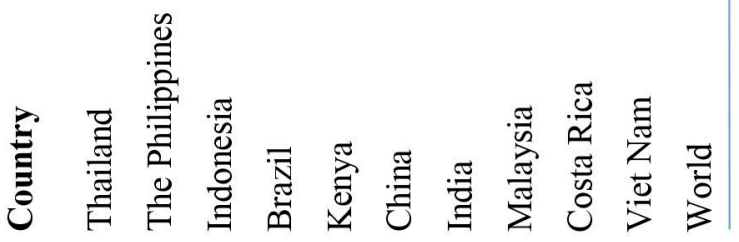




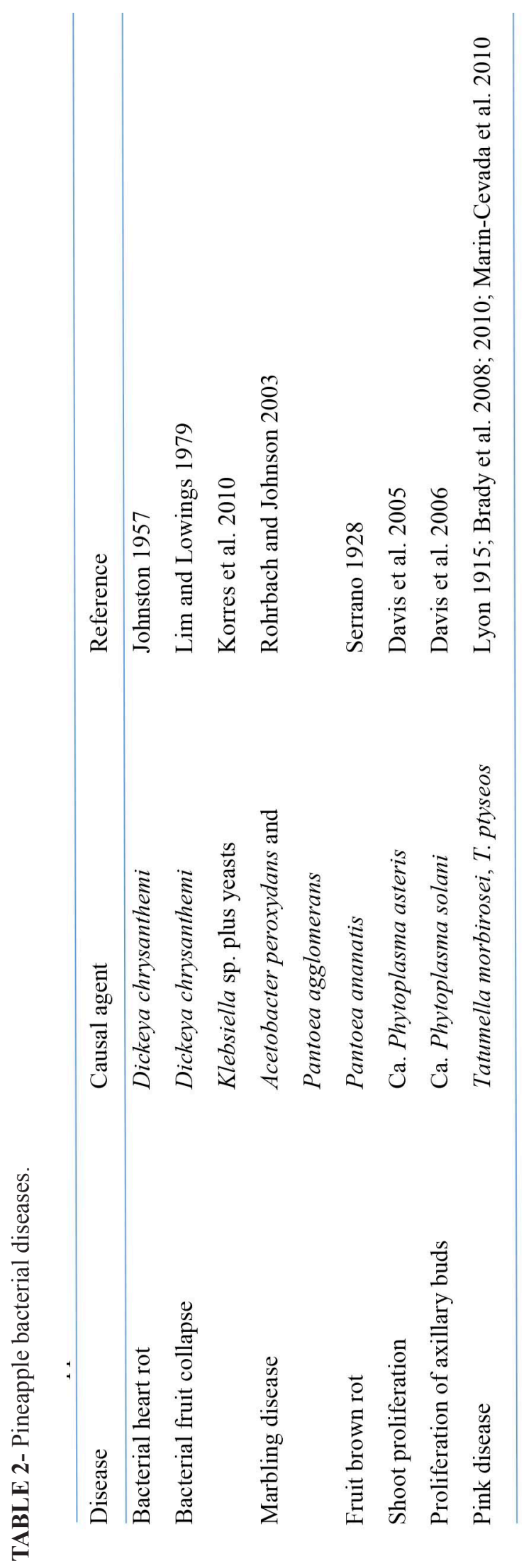

Rev. Bras. Frutic., v. 38, n. 3: (e-949) 


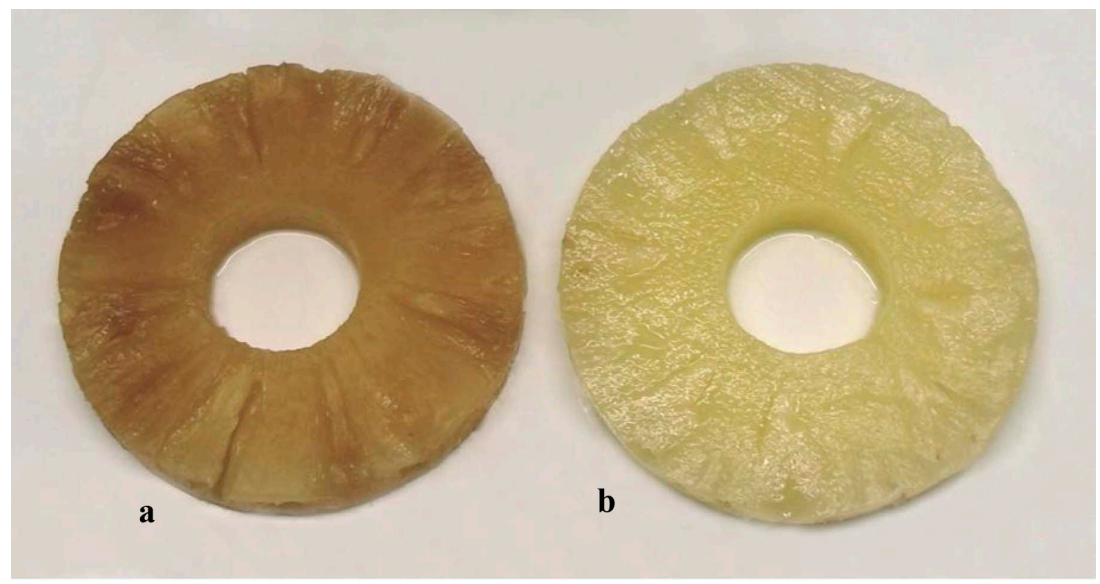

FIGURE 1 - Canned pineapple affected (a) compared to unaffected (b) by pink disease.

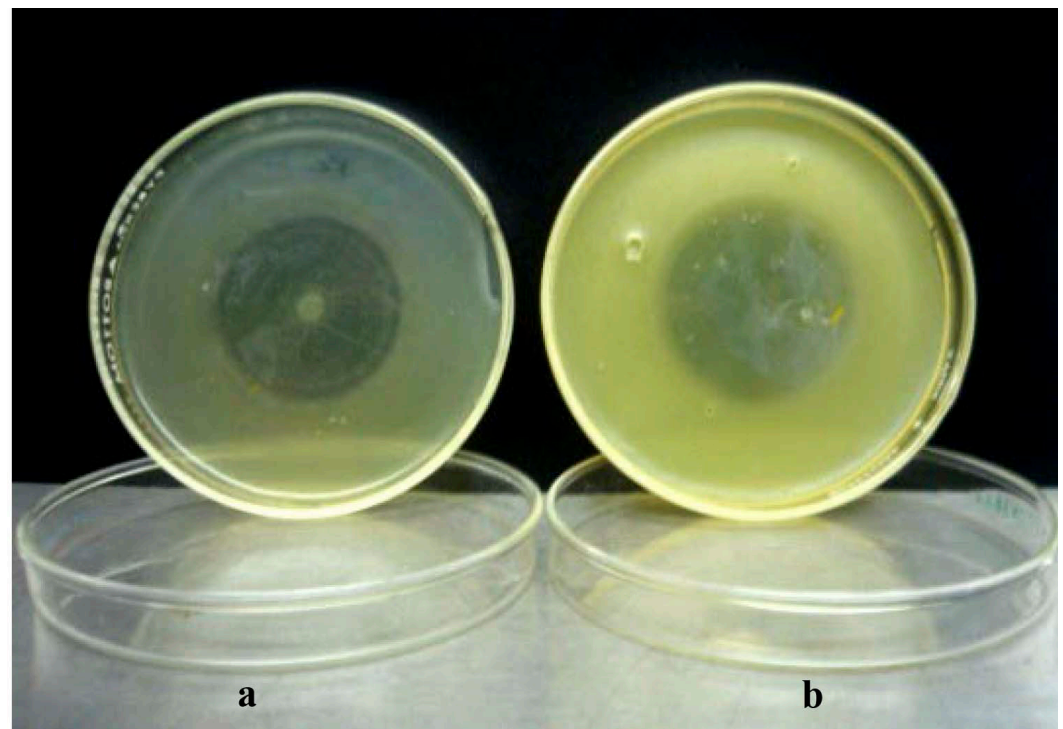

FIGURE 2- Antagonistic activity in solid media.

\section{CONCLUSIONS}

The understanding of interactions between pineapple, Tatumella, B. gladioli, other potential antagonists, and the environment is imperative to design preventive and control strategies for pink disease. Comparative genomic studies of the causal agents and of their antagonists might reveal genes involved in virulence and genes involved in antibiosis. Additionally, the search for new pineapple genotypes that are more resistant to pink disease could greatly reduce the economic impact of this disease in pineapple market.

\section{ACKNOWLEDGMENTS}

Work in the author's laboratory was funded by Consejo Nacional de Ciencia y Tecnología, México, Grant CB-2009-128235-z and VIEP-BUAP. We appreciate the valuable comments and language review by Michael Dunn (Centro de Ciencias Genómicas, UNAM, México) and Antonino Baez (ICUAP-BUAP). We acknowledge the comments of an anonymous referee. We are grateful to Luciana Schultze Nobre (Environ. Biotechnol. Dept. Helmholtz Center Environ. Res.-UFZ), and to Aldo Bazán Herrera for their Portuguese edition. 


\section{REFERENCES}

BARTHOLOMEW, D.P.; PAUL, R.E.; ROHRBACH, K.G. The pineapple: botany, production and uses. Wallingford: CABI Publishing, 2003.

BRADY, C.; CLEENWERCK, I.; VENTER, S.; VANCANNEYT, M.; SWINGS, J.; COUTINHO, T. Phylogeny and identification of Pantoea species associated with plants, humans and the natural environment based on multilocus sequence analysis (MLSA). Systematic and Applied Microbiology, Stuttgart, v.31, n.6-8, p.460, 2008.

BRADY, C.L.; VENTER, S.N.; CLEENWERCK, I.; VANDEMEULEBROECKE, K.; DE VOS, P.; COUTINHO, T.A. Transfer of Pantoea citrea, Pantoea punctata and Pantoea terrea to the genus Tatumella emend. as Tatumella citrea comb. nov. Tatumella punctata comb. nov., and Tatumella terrea comb. nov. (Kageyama et al., 1992) and description of Tatumella morbirosei sp.nov. International Journal Systematic Evolutionary Microbiology, Reading, v.60, n.3, p.484-494, 2010.

BUDDENHAGEN, I.W.; DULL, G.G. Pink disease of pineapple fruit caused by strains of acetic acid bacteria. Phytopathology, St Paul, v.57, p.806, 1967.

CHA, J.S.; PUJOL, C.J.; DUCUSIN, A.R., MACION, E.A.; HUBBARD, C.H.; KADO, C.I. Studies on Pantoea citrea, the causal agent of pink disease of pineapple. Jounal of Phytopathology, Utrecht, v.145, p.313-320, 1997a.

CHA, J.; PUJOL, C.; KADO, C.I. Identification and characterization of a Pantoea citrea gene encoding glucose dehydrogenase that is essential for causing pink disease of pineapple. Applied and Environmental Microbiology, Washington, v.63, n.1, p.71-76, 1997b.

CHO, J.J.; HAYWARD, A.C.; ROHRBACH, K.G. Nutritional requirements and biochemical activities of pineapple pink disease bacterial strain from Hawaii. Antonie Van Leeuwenhoek, Dordrecht, v.46, n.2, p.191-204, 1980.

COLLINS, J..L. The pineapple: botany, utilization, cultivation. London: Leonard Hill, 1960.

DAVIS, R.I.; AROCHA, Y.; JONES, P.; MALAU, A. First report of the association of phytoplasmas with plant diseases in the territory of Wallis and Futuna. Australasian Plant Pathology, Clayton, v.34, p.417-418, 2005.
DAVIS, R.I.; JONES, P.; HOLMAN, T.J.; HALSEY, K.; AMICE, R.; TUPOUNIUA, S.K.; SETH, M. Phytoplasma disease surveys in Tonga, New Caledonia and Vanuatu. Australasian Plant Pathology, Clayton, v.35, n.3, p.335-340, 2006.

FAO. Medium-term prospects for agricultural commodities. Projections to the year 2010. Rome, 2003. (Technical Paper, 1)

GAVINI, J.; MERGAERT, J.; BENJI, A.; MIELCAREK, C.; IZARD, D.; KESTERS, K.; DE LEY, J. Transfer of Enterobacter agglomerans (Beijerinck 1888) Ewing and Fife 1972 to Pantoea gen. nov. as Pantoea agglomerans comb. nov. and description of Pantoea dispersa sp.nov. International Journal of Systematic Bacteriology, Ames, v.39, p.337-345,1989.

GOSSELE, F.; SWINGS, J. Identification of Acetobacter liquefaciens as causal agent of pinkdisease of pineapple fruit. Jounal of Phytopathology, Utrecht, v.116, n.3, p.167-175, 1986.

HINE, R.B. Epidemiology of pink disease of pineapple fruit. Phytopathology, St Paul, v.66, p.323-327, 1976.

JOHNSTON, A. Bacterial heart rot of the pineapple. Malaysian Agricultural Journal, Kuala Lumpur, v.40, n.1, p.2-8, 1957.

KADO, C.I. Pink disease of pineapple. Saint Paul: The American Phytopathological Society, 2003. Disponível em: $\leq \mathrm{http}$ ://www.apsnet.org/publications/ apsnetfeatures/Pages/Pineapple.aspx $>$. Acesso em: 27 abr. 2015.

KONTAXIS, D.G.; HAYWARD, A.C. The pathogen and symptomatology of pink disease of pineapple fruit in the Philippines. Plant Disease Reporter, Washington, v.62, p.446-450, 1978.

KORRES, A.M.N.; VENTURA, J.A.; FERNANDES, P.M.B. First report of bacterium and yeasts associated with pineapple fruit collapse in Espírito Santo State, Brazil. Plant Disease, New York, v.54, n.12, p.1509, 2010

LIM, W.H.; LOWINGS, P.H. Pineapple fruit collapse in Peninsular Malaysia: symptoms and varietal susceptibility. Plant Disease Reporter, Washington, v.63, p.170-174, 1979. 
LOEILLET, D.; DAWSON, C.; PAQUI, T. Fresh pineapple market: from the banal to the vulgar. Acta Horticulturae, The Hague, v.902, p.587-594, 2011.

LUTHER, H.E. An alphabetic list of bromeliad binomials. $13^{\text {th }}$ ed. Sarasota: Marie Selby Botanical Gardens \& Bromeliad Society International, 2012.

LYON, H.L. A survey of the pineapple problems. Hawaii Plant Recreation, Honolulu, v.13, p.125139, 1915.

MARÍN-CEVADA, V.; VARGAS, H.V.; JUÁREZ, M.; LÓPEZ, V.G.; ZAGADA, G.; HERNÁNDEZ, S.; CRUZ, A.; CABALLERO-MELLADO, J.; LÓPEZREYES, L.; JIMÉNEZ-SALGADO, T.; CARCAÑOMONTIEL, M.; FUENTES-RAMÍREZ, L.E. First report of the presence of Pantoea citrea, causal agent of pink disease, in pineapple fields grown in Mexico. Plant Pathology, Oxford, v.55, n.12, p.294, 2006.

MARÍN-CEVADA, V.; CABALLERO-MELLADO, J.; BUSTILLOS-CRISTALES, R.; MUÑOZ-ROJAS, J.; MASCARÚA-ESPARZA, M.A.; CASTAÑEDALUCIO, M.; LÓPEZ-REYES, L.; MARTÍNEZAGUILAR, L.; FUENTES-RAMÍREZ, L.E. Tatumella ptyseos, an unrevealed causative agent of pink disease in pineapple. Journal Phytopatholy, Utrecht, v.158, n.2, p.93-99, 2010.

MARÍN-CEVADA, V.; MUÑOZ-ROJAS，J.; CABALLERO-MELLADO, J.; MASCARÚAESPARZA, M.A.; CASTAÑEDA-LUCIO, M.; CARREÑO-LÓPEZ, R.; ESTRADA-DE LOS SANTOS, P.; FUENTES-RAMÍREZ, L.E. Antagonistic interactions among bacteria inhabiting pineapple. Applied Soil Ecology, New York, v.61, p.230-235, 2012.

PUJOL, C.; KADO, C.I. gdhB, a gene encoding a second quinoprotein glucose dehydrogenase in Pantoea citrae, is required for pink disease of pineapple. Microbiology, New York, v.145, n.5, p.1217-1226, 1999.
PUJOL, C.; KADO, C.I. Genetic and biochemical characterization of the pathway in Pantoea citrea leading to pink disease of pineapple. Journal of Bacteriology, Washigton, v.182, p.2230-2237, 2000. ROHRBACH, K.G.; JOHNSON, M.W. Pest diseases and weeds. In: BARTHOLOMEW, D.P.; PAULL, R.E.; ROHRBACH, K.G. (Ed.). The pineapple: botany, production and uses. Wallingford: CABI Publishing, 2003. p.203-251.

ROHRBACH, K.G.; PFEIFFER, J.B. The field induction of bacterial pink disease in pineapple fruit. Phytopathology, St Paul, v.65, p.803-805, 1975.

ROHRBACH, K.G.; PFEIFFER, J.B. The interaction of four bacteria causing pink disease of pineapple with several pineapple cultivars. Phytopathology, St Paul, v.66, p.396-399, 1976.

ROHRBACH, K.G. Pineapple diseases and pest and their potential for spread. In: SINGH, K.G. (Ed.). Exotic plant quarantine pests and procedures for introduction of plant materials. Serdang: ASEAN Plant Quarantine Centre and Training Institute, 1983. p.145-171.

ROHRBACH, K.G. Unusual tropical fruit diseases with extended latent periods. Plant Disease, New York, v.73, p.607-609, 1989.

SERRANO, F.B. Bacterial fruitlet brown rot of pineapple. Philippine Journal of Science, Manila, v.36, p.271-305, 1928.

SUÁREZ-MORENO, Z.R.; CABALLEROMELLADO, J.; COUTINHO, B.G.; MENDONÇAPREVIATO, L.; JAMES, E.K.; VENTURI, V. Common features of environmental and potentially beneficial plant-associated Burkholderia. Microbial Ecology, New York, v.63, p.249-266, 2012.

ZHANG, J.; MALEZIEUX, E.; BARTHOLOMEW, D.P.; ALOHA- Pineapple v.2.1: a computer model to predict the growth, development and yield of pineapple. Acta Horticulturae, The Hague, v.425, p.287-296, 1997. 